\title{
PROTECTION OF TEMPORARY FOREIGN WORKERS: THE CASE OF FILIPINOS IN CANADA
}

\author{
by \\ Kwan Ho Leung \\ BA, University of Wisconsin-Milwaukee, 1990; MA, University of Wisconsin-Milwaukee, 1991; \\ MA, Wayne State University, 1995 \\ A Major Research Paper \\ presented to Ryerson University \\ in partial fulfillment of the requirements for the degree of \\ Master of Arts \\ in the Program of \\ Immigration and Settlement Studies
}

Toronto, Ontario, Canada, 2013

(C) Kwan Ho Leung 2013 


\section{AUTHOR'S DECLARATION FOR ELECTRONIC SUBMISSION OF A MAJOR RESEARCH PAPER (MRP)}

I hereby declare that I am the sole author of this Major Research Paper. This is a true copy of the MRP, including any required final revisions, as accepted by my examiners.

I authorize Ryerson University to lend this MRP to other institutions or individuals for the purpose of scholarly research.

I further authorize Ryerson University to reproduce this MRP by photocopying or by other means, in total or in part, at the request of other institutions or individuals for the purpose of scholarly research.

I understand that my MRP may be made electronically available to the public.

Kwan Ho Leung 


\title{
PROTECTION OF TEMPORARY FOREIGN WORKERS: \\ THE CASE OF FILIPINOS IN CANADA
}

\author{
Kwan Ho Leung \\ Master of Arts 2013 \\ Immigration and Settlement Studies \\ Ryerson University
}

\begin{abstract}
Temporary foreign workers have been employed — or simply used—throughout history. Their plights have gained some attention across the globe in recent decades. Canada as a major receiving country of these workers and the Philippines as a prolific sending country of workers are selected as case studies to examine whether measures taken internationally, nationally and locally are adequate to protect these workers, especially those in low-skilled occupations. Based on prior research on the workers' well-being, the answer is no in at least five areas: recruitment, matching of qualifications, abuse, housing, and family separation. Suggestions are made to address these specific areas. In addition, it is argued that, in order to protect the workers, civil society should also be involved and expanded rights should be given to the workers.
\end{abstract}

\section{Key words:}

Temporary foreign workers; Filipinos; Protection; Civil Society; Citizenship 


\section{ACKNOWLEDGEMENTS}

I would like to thank Dr. Arthur Ross, my supervisor, for patiently guiding me and giving me valuable feedback in the long process of completing this paper-from the initial meeting in March to the oral defence in September; Dr. Myer Siemiatycki, my second reader, for prompt responses, constructive comments and a disarming demeanour at the defence; and Dr. Francis Hare and Ms. Elias Chu for keeping this one-of-a-kind program going.

My gratitude also goes to some friends and family members. Telephone calls from Tim Yue and Yew-mun Yip and Facebook exchanges with members of my cohort-especially Candace Westman, Cristina Doré Bari, Emma Flynn, and Rosalind Gunn—were perfect venues for lamenting and laughing. Aunt Cecilia's familial love behind her financial help meant more to me than the money. There is also my late sister, Wing Sze: An example of diligence and perfection, she had helped me finish this degree in an unspoken way.

Although I had obtained three degrees prior to enrollment in the ISS program, my parents had not been able to attend any of the convocations due to work. They will come for the ISS one and this degree is dedicated to them: "Thank you, Mom and Dad."

Finally, I thank God for the time, talent and tenacity that He has given me to learn something new, including the experiences of a group of fine women who have been toiling hard for their families and have been an inspiration for this paper and this author: The Filipinas working abroad. 


\section{Table of Contents}

Author's Declaration...................................................................................ii

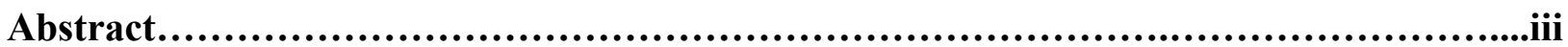

Acknowledgements..........................................................................iv

Table of Contents............................................................................v

Chapter 1: $\quad$ Introduction......................................................................1

Chapter 2: Canada's Programs for Low-Skilled Temporary Foreign Workers.............6

Chapter 3: The Philippines' Labour-Exporting Experience...............................10

Chapter 4: Measures to Protect Temporary Foreign Workers by the Philippines and

Canada..........................................................................12

4.1: International and Bilateral Agreements............................... 12

4.2: National Measures Taken in the Philippines............................ 16

4.3: Federal and Provincial Measures Taken in Canada........................18

Chapter 5: The Well-Being of Filipino Low-Skilled Temporary Foreign Workers in

Canada.....................................................................22

5.1: Recruitment.................................................22

5.2: Mismatch of Skills.................................................24

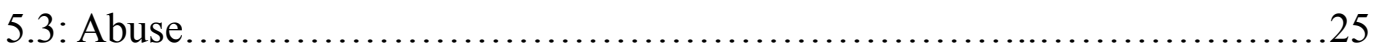

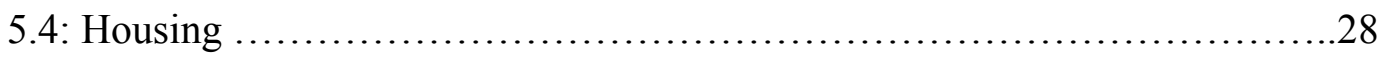

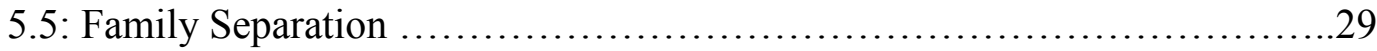

5.6 Other Low-Skilled Temporary Foreign Workers .........................30

5.7 Citizenship Rights .................................................. 31 
Chapter 6: Improving Temporary Foreign Workers' Welfare

6.1: Suggestions for Specific Areas of Welfare.............................34

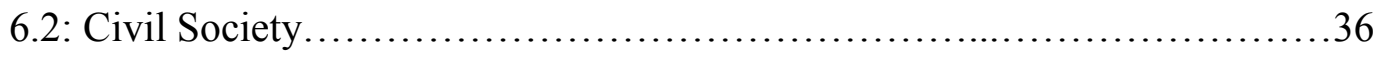

6.3: Permanent Residence and Labour Market Rights...........................39

Chapter 7: Conclusion.................................................................43

References...................................................................................45 


\section{Chapter 1 Introduction}

Labour migration across national borders has occurred throughout history. At one extreme, slavery and human trafficking provided receiving countries with unwilling and unprotected workers. At the other extreme, individual voluntary decisions to seek better opportunities abroad have produced a workforce of diverse skills. However, most migrants may fall between the two extremes: they see no choice but to find employment elsewhere because of various political, economic or family reasons. For a country, accepting or sending migrant workers can be of national economic benefit. For example, foreigners can fill local labour shortages in the receiving countries (Ruhs, 2005) and employment abroad can absorb an excessive supply of domestic workers in the sending countries (Fitzgerald, 2006). Throughout its history, Canada has encouraged and accepted foreigners to meet its labour market needs, whether it is for construction, farm work, or domestic help (Kelley \& Trebilcock, 2010).

As evidenced by the growth of international actions for migrant workers' welfare in the last few decades, what may be unique about labour migration in modern times is the recognition of the need to protect the well-being of these workers, especially those who stay in the receiving states temporarily and enjoy few rights. Specifically, various international conventions, government initiatives, and non-governmental organizations have been established since the end of the Second World War. For example, the Convention on the Protection of the Rights of Migrant Workers and Members of their Families of 1990 enshrines a number of rights for these workers - such as, proper wages and family reunion — and some of these have been extended to illegal migrants (MacDonald \& Cholewinski, 2007). Moreover, bilateral agreements on such labour migration issues as the recruitment process have been made by countries all over the world (for examples, see Organization for Economic Development and Cooperation, 2004). 
Finally, non-governmental groups that advocate for migrant workers have been active across the globe. One such group is Migrante International. It was formed in 1995 to voice concerns over the lack of support for Filipino workers from their home government (Migrante International, 2013).

Concerns about the welfare of workers may be especially important for those considered low-skilled. The temporary migration of these workers is supposed to be beneficial to the workers themselves because they can earn a higher income than they would at home (Blouin, 2005; Dacuycuy, 2009). However, low-skilled temporary foreign workers (TFWs) tend to be treated worse in the receiving country than their better-trained compatriots. For example, in Canada, the latter can choose their own residence, have their spouse receive a work permit and enjoy eligibility for programs for permanent residence such as the Canadian Experience Class. Many of these privileges are denied to low-skilled TFWs, leaving them, for example, dependent on the employer for housing and income and separated from their families for months.

International concerns and treatments of TFWs" rights highlight the "precarious status" of these workers (Goldring, 2010, p. 50). Goldring (2010) defines this status as the absence of rights that are granted to citizens and permanent residents: working, staying permanently, residing independently from any legal link to another party (e.g., an employer), enjoying social services, and sponsoring family members. TFWs, especially those of low skills, certainly fit this definition. Although they are allowed to work, many do not have the right to permanent residence, family reunion and some public services, and their current ability to stay in a country depends on their employment. Such a precarious status means both the exclusion of these workers from the full range of services deemed appropriate for citizens/permanent residents and the explicit recognition of an artificial "two-tier membership" (p. 53) with different classes of 
residents in the receiving country. The latter issue can be a problem for a country, such as Canada, that identifies itself with equality among people: Differential treatments accorded to its own citizens and TFWs of different skill levels can be in conflict with the dominant values of the country (Goldring, 2010; Tungohan, 2012).

Governments in the receiving countries are in a strong position to develop policies to affect the plights and rights of TFWs. Ruhs (2005) has classified a few elements for these policies: first, the primary objectives-for example, meeting labour shortage, discouraging illegal immigration, strengthening bilateral ties or providing workers with new skills to further economic development in the sending country; second, the admission mechanism—-for example, employer requests, bilateral agreements, or quotas on different kinds of workers; third, the criteria of selection-for example, the economic sector or the worker's skill level; and finally, post-admission protection—-for example, TFWs' eligibility for social services.

Although Ruhs' (2005) scheme is concerned with the actions of receiving countries, sending countries can likewise develop policy approaches to labour migration based on these four elements. These countries should also examine what to do with returned workers and how to respond to the receiving countries' foreign worker labour policies and practices - after all, labour-exporting countries depend on labour-receiving countries for the absorption of their excess workers and the generation of foreign exchange.

Governmental actions, however, may be limited in their impacts on the welfare of TFWs. Much like the local populace using informal community support for many of their needs, TFWs can likewise seek help among themselves or from the local community when they face difficulties (for example, loneliness). Hence, the importance of civil society should not be ignored in any examination of the welfare of migrant workers (Gibb, 2010). 
Given international interests in migrant workers' rights, this paper is an attempt to scrutinize what the Philippines and Canada have done to protect the well-being of low-skilled Filipino TFWs in Canada, what problems these workers face despite government actions, and what else these countries can do in this regard. Specifically, it argues that existing government policies to protect low-skilled TFWs are inadequate in a number of areas of their well-being. Furthermore, it advocates for an expanded range of rights for these workers, including the right to permanent residence, and the increased involvement of civil society in the labour-receiving country as means to strengthen the welfare of TFWs.

The Philippines and Canada have been chosen because a discussion of a topic such as this necessitates restricting the scope of the paper. Because labour migration occurs around the globe and there are similar challenges faced by migrant workers, exemplar cases must be used to illustrate the issues. With 338,189 TFWs present in the country in 2012 (Citizenship and Immigration Canada [CIC], 2013a) and with specific programs for TFWs of different skill levels and occupations, Canada can serve as an example of what a receiving country has done and can do better for the welfare of TFWs. Similarly, with a contingent of 45,450 Filipino workers in Canada as of December 1, 2011 (CIC, 2012c) and a long-standing labour-exporting policy, the Philippines provides a good case study of how migrant workers are treated by their home government and what improvements may be needed to protect them. An examination of these two countries' experiences should encourage not only both Canada and the Philippines, but also others around the world, to improve their treatment of TFWs.

One important point to keep in mind is the reference to the workers' skill level in this paper. For convenience and consistency with other research work, the terms "low-skilled workers" and "high-skilled workers" are used interchangeably with the terms "workers in low- 
skilled occupations" and "workers in high-skilled occupations." However, not all workers in low-skilled occupations are uneducated or devoid of professional expertise. In fact, some migrant workers with high qualifications are willing to participate in entry-level occupations outside their home countries in order to earn a decent income and a chance for emigration (Lowe, 2012) and, in Canada's case, some employers intentionally hire overqualified foreigners to do menial jobs to ensure the workers can speak English (Thomas, 2010).

The organization of the paper is as follows. Chapter 1 introduces the topic. Chapter 2 surveys Canada's temporary foreign worker programs with low-skilled Filipinos. Chapter 3 outlines the labour-sending history of the Philippines. Chapter 4 examines the Philippines' and Canadian (both federal and provincial) measures to protect low-skilled Filipino TFWs in Canada. Chapter 5 discusses the plights of low-skilled Filipino temporary foreign workers in Canada to highlight the limitations of the measures mentioned in Chapter 4. Chapter 6 offers specific suggestions and proposes the expansion of rights and the use of civil society to remedy any inadequacy of protection. Chapter 7 concludes the paper. 


\section{Chapter 2 Canada's Programs for Low-Skilled Temporary Foreign Workers}

Canada’s Temporary Foreign Worker Program officially began in 1973 (Nakache, 2010).

Before that, foreigners who entered the country for employment purpose were considered visitors unless they worked in certain industries such as mining (Trumper \& Wong, 2007). The original goal was to allow professionals such as engineers and academics to work in this country (Nakache, 2010). In 2002, the Canadian government expanded the program to include the Pilot Project for Hiring Foreign Workers in Occupations Requiring Lower Levels of Formal Training in response to the growing demand for low-skilled TFWs (Nakache, 2010). Further changes to facilitate the employment of TFWs, such as shortening the period for advertising a job vacancy to Canadians to seven days, have been implemented in recent years as the Canadian government pushes for greater and greater flexibility in the workforce (Flecker, 2010; Siemiatycki, 2010).

TFWs have, indeed, become an important part of the Canadian labour market. In 1980, this group (excluding non-program TFWs such as foreign students and refugee claimants) accounted for $0.2 \%$ of the workforce. In 2011, the proportion reached $1.6 \%$ (Kustec, 2012). The rise has occurred nationwide. From 2008 to 2012, with minor fluctuations in some areas of Canada, there were increases in the number of TFWs in all provinces and territories (CIC, 2013a). As of December 1, 2012, there were 338,189 TFWs in Canada (CIC, 2013a). In 2012 alone, 213,516 made their first entries or re-entries to the country (CIC, 2013b). Another indication of Canada's rising dependence on TFWs is the number of positive Labour Market Opinions (LMOs) issued by the Human Resources and Skills Development Canada (HRSDC) for positions that require LMO approval. The LMO specifies the need for TFWs and the impact on the Canadian labour market and a positive decision permits an employer to hire workers from abroad. The total number of approved positions increased from 131,645 in 2009 to 202,510 in 
2012 (HRSDC, 2013). Although an LMO approval does not guarantee the arrival of a worker, the aggregate number of approvals does demonstrate—barring any misinformation provided by employers to the HRSDC - the extent to which employers want to fill jobs that they cannot find Canadian workers to take. The demand for TFWs has risen faster in occupations that do not require professional, management or technical expertise than in those that do: the increase in the former is 4-10 times higher than that in the latter (Lowe, 2012).

Curiously, employer demands for TFWs do not always match the state of the Canadian economy. For example, even when the manufacturing sector in Ontario was slowing down (and thus, providing candidates for job vacancies), TFWs were still being recruited to fill low-skilled jobs in the province (Byl, 2010). This suggests that some employers may have found advantages in hiring TFWs that outweigh both the costs of recruiting them and the benefits of using Canadian workers. As will be discussed in Chapter 5, one such advantage may be the TFWs' weak bargaining position due to their desire for an income and permanent residence in Canada.

Canada classifies low-skilled TFW occupations into different categories (DepatiePelletier, 2010). Two in particular are of relevance to this paper because of the participation of Filipino TFWs - the Live-in Caregiver Program and the Pilot Project for Hiring Foreign Workers in Occupations Requiring Lower Levels of Formal Training ("Low-skilled Pilot").

The Live-in Caregiver Program (LCP) is intended to find workers to take care of the young, the old or the disabled in a private family home. Admission to this program is employerdriven, with families finding their helpers through employment agencies or other channels. The LCP participant must live in the employer's home on work days. After having fulfilled 24 months of service, the worker is eligible to apply for permanent residence and is entitled to an 
open work permit while waiting for approval (CIC, 2012b). As of December 1, 2011, there were 24,604 workers in the LCP (CIC, 2012c).

Canadian government ministers and international organizations have claimed that the LCP is a successful instrument for low-skilled workers to immigrate to Canada (Brickner \& Straehle, 2010). Most of the program alumni have applied for and received permanent residence in the country (Brickner \& Straehle, 2010). Because women make up the majority of the participants in the LCP, the program provides an option for women who may otherwise have difficulty meeting the skill and education requirements of the Federal Skilled Worker Program to move to Canada (Brickner \& Straehle, 2010).

Another Canadian TFW program that is of relevance to this paper is the Low-skilled Pilot. It was designed to meet the labour demands for low-skill occupations - defined as Levels $\mathrm{C}$ and $\mathrm{D}$ in the National Occupation Classification (NOC). NOC C occupations require 1-4 years of secondary school education and a maximum of two years of work experience or on-the-jobtraining while NOC D occupations need only two years of secondary school at most (Hennebry, 2010). NOC C occupations include machine operators in food processing and sales representatives among others while those in NOC D include food counter helpers and landscaping labourers (HRSDC, 2012a). As suggested earlier, the labour demand for both levels of occupations have increased. Between 2002 and 2008, the number of the higher-level NOC O, A, and B jobs increased by $15.5 \%$ while NOC C jobs jumped by $56 \%$, but this large increase was dwarfed by the 16-fold increase in NOC D positions (Lowe, 2012). Workers are recruited by the employers and are not eligible for permanent residence through the program. To some critics of Canada's immigration policy, the need for TFWs in low-skilled jobs shows that the Federal 
Skilled Workers' Program is not capable of meeting the labour market needs of Canada (Lowe, 2012).

In spite of their differences, both the LCP and the Low-skilled Pilot programs share the requirements that the employer must bear the recruitment costs, pay for the roundtrip airfare of the worker, and secure private or provincial health care coverage. 


\section{Chapter 3 The Philippines' Labour-Exporting Experience}

The Philippines is perhaps the most prolific labour exporter in the world. At the end of 2011, over 4.5 million Filipinos were being employed as temporary workers in 227 countries and territories across the globe (Commission on Filipinos Overseas, 2013). Between 2003 and 2009, a million Filipinos left the country for work abroad annually, occupying positions of various skill levels, from domestic helpers to engineers (Ordonez, 2012) and reaching the government's official annual target of foreign deployment of workers (Asis \& Agunios, 2012).

The economic contribution of this overseas labour force to the Philippines is significant. Remittances amounted to 11\% of the country's GDP in 2011 (Bangko Sentral ng Pilipinas, 2012, as cited in Dimaya, McEwen, Curry \& Bradley, 2012, p. 1). In 2010, a total of US\$18B was sent to the Philippines from its diaspora (Pernia, 2011, as cited in Ordonez, 2012, p. 46). Unlike the production of goods that require materials from foreign countries, workers employed abroad bring in income with almost no financial cost to the Philippines and stimulate its national economy through a ripple effect on consumer spending and related businesses such as travel companies and recruitment agencies (De Castro, 2010). Perhaps as much as half of the Philippine population receives some support from remittances (De Castro, 2010).

The migrant workers' economic contributions to the Philippines involve many personal sacrifices. Many endure poor living conditions, low pay and long hours in their overseas jobs (Rodriguez, 2011). Some have gone through multiple deployments, trying to accumulate work experience to appeal to employers in more-desirable countries and to save enough money to pay for the higher recruitment fees needed to go to those countries (Paul, 2011). Many also have suffered from abuse by their employers and, when they seek help, the indifference of Philippine officials stationed overseas (Migrante International, 2009). Given their contributions and 
sacrifices, overseas Filipino workers are intentionally depicted as heroes by the popular media and the government (Bach \& Solomon, 2008; Martin, Abella, \& Midgley, 2004).

The Philippine government adopted an official labour-exporting policy in 1974 when the Middle East oil crisis of 1973 necessitated the need to acquire foreign currency (Bach \& Solomon, 2008). The policy was supposed to last for a short time, but the country's dependence on remittances has turned it into a permanent measure (Bach \& Solomon, 2008). The policy has since helped to alleviate the pressure of unemployment and to reduce foreign exchange deficits (De Castro, 2010). Under this policy, the government actively promotes, trains, and recruits Philippine workers for foreign assignments (Dacuycuy, 2009; Dimaya et al., 2012). For example, the Philippine Overseas Employment Administration (POEA) regulates employment agencies (Dacuycuy, 2009), gives workers a pre-departure orientation (Rodriguez, 2011), and works with other departments such as the Technical Education and Skills Development Authority to develop skill training to meet foreign countries' needs (Rodriguez, 2011).

Considered an excellent example in migration management (Dacuycuy, 2009; Gibb, 2010), the Philippines not only promotes the export of labour but also implements measures to protect its workers overseas. As discussed in the next chapter, there are government departments set up for just this purpose, and protecting workers has been a key component of the Philippines' foreign policy (De Castro, 2010). Nevertheless, as a recent story of how Philippine officials in Saudi Arabia allegedly failed to house and repatriate Filipino workers who had escaped from abusive employers indicates ("Tent," 2013), the Philippine government is limited in what it can do to help workers overseas due to legal constraints and political considerations such as its desire to maintain friendly relations with countries that accept migrant workers (De Castro, 2010). 


\section{Chapter 4 Measures to Protect Temporary Foreign Workers by the Philippines and Canada}

Given the TFWs' contributions to the economies of the sending and receiving countries, many governments have enacted various measures to protect their well-being. However, because a government's legal authority is largely limited to the territory it controls, there is a kind of division of labour between labour-exporting and labour-importing countries. The sending countries tend to be concerned with the pre-deployment and post-return welfare of the migrant workers while the receiving countries are mainly responsible for the well-being of the workers during their work period overseas (Dacuycuy, 2009). Moreover, in a federated state, labour protection is usually the jurisdiction of local authorities, not the national government, of the receiving country (Piper, 2004). The cases of the Philippines and Canada - their international agreements and individual actions — can demonstrate some of the measures taken at the international, national and local levels to protect TFWs, especially those with low skills.

\section{1: International and Bilateral Agreements}

Like many labour-sending countries, the Philippines tries to protect its overseas workers' welfare through multilateral and bilateral agreements. It was an active proponent of the United Nations' Convention on the Protection of the Rights of Migrant Workers and Members of their Families (De Castro, 2010) and was the first Asian country to ratify this document (Dacuycuy, 2009). The Convention enshrines a number of rights and freedoms for migrant workers, including receiving the same wages as locals, forming labour organizations, access to urgent medical care, protection against dismissal, movement within a territory, unification of spouses and dependent minor children, and their children's access to education (MacDonald \& Cholewinski, 2007). The Philippines has also signed Conventions 97 and 143 of the International Labour Organization (ILO) (Piper, 2004). These two documents oblige signatory 
states to foster migrant workers' access to items that can facilitate their stay in the host society: information, social benefits, unionization, family reunion, etc. (ILO, 2012a; 2012b).

Although labour-sending countries may be enthusiastic about developing and signing international conventions on migrant workers' rights, labour importers tend to be reluctant to ratify these documents. For example, many of these countries have refused to sign the Convention on the Protection of the Rights of Migrant Workers and Members of their Families due to fears of the document's infringement on their rights to control immigration (Ruhs, 2012). Canada is a member of this group partly because the country's rules to restrict low-skilled TFWs to specific occupations may contradict the Convention (Ruhs, 2012). The country has also not signed either of the ILO conventions mentioned above (ILO, 2012c). Because labour-receiving countries' policies have direct impact on migrant workers' well-being, their focus on national interests and the consequent failure to accept international conventions shows the futility of pursuing these efforts for the purpose of protecting migrant workers by labour-sending countries.

In addition to global-level agreements, bilateral accords are also used to protect the welfare of foreign workers. Though non-binding legally, they can set guidelines for important areas of the workers' and employers' well-being such as working conditions and dispute resolution (Blank, 2011). Their significance may be illustrated by the demands for such agreements by virtually all stakeholders in labour migration in the Philippines—politicians, officials, recruitment agencies and non-governmental organizations (NGOs) (Blank, 2011; Dimaya et al., 2012).

The Philippines has signed a Memorandum of Understanding (MOU) on its temporary workers with each of the four western provinces in Canada. All four MOUs deal with the same issues - recruitment, orientation, training, post-deployment welfare in a province, and post-return 
living in the Philippines (Department of Labor and Employment of the Government of the Republic of the Philippines and Department of Advanced Education and Employment of the Province of Saskatchewan of Canada, 2006; Department of Labor and Employment of the Republic of the Philippines and Ministry of Employment and Immigration of Alberta, 2008; Government of British Columbia and Government of the Philippines, 2008; Government of the Philippines and Government of Manitoba, Canada, 2008). The one between the Philippines and British Columbia exemplifies the contents of all of them.

In this MOU, a large number of clauses are concerned with the recruitment process. The Philippine Department of Labor and Employment (DOLE) agrees to send the British Columbia Ministry of Economic Development a list of approved employment agencies periodically. The DOLE also provides an orientation to workers to help them understand their terms of employment and, with information from the British Columbia government, their rights and benefits in the province (Government of British Columbia and Government of the Philippines, 2008). Prospective Canadian employers, who must be registered with the DOLE, can seek workers from the accredited agencies—or through other means as long as the hiring process does not violate the Philippine Labor Code — and they assume responsibility for all the hiring costs (Government of British Columbia and Government of the Philippines, 2008).

Except for recruitment, the MOU provides a relatively brief and vague description of the involvement of both the Philippines and British Columbia on other issues: For example, the Philippine Overseas Labour Office in Toronto monitors whether Filipino workers in the province are protected under Canadian and provincial laws while the province supports the Philippines' efforts to improve its education for Filipino youth and reintegrate returned workers (Government of the Philippines and Government of British Columbia, 2008). 
Despite their lofty provisions, international and bilateral agreements are not always good instruments for the protection of foreign workers. Although labour-sending countries tend to favour these conventions because they promote, rather than restrict, migrant workers' rights and freedoms in the receiving country (De Castro, 2010; MacDonald \& Cholewinski, 2007), labourreceiving countries may not sign the conventions for the same reason-as Canada's experience with the Convention on the Protection of the Rights of Migrant Workers and Members of their Families shows. As for bilateral agreements, a potential partner can refuse to enter into negotiation due to fear of losing control over the issue concerned. For example, the Philippines has been unable to secure Saudi Arabia's cooperation due to the Saudi's fear of having to develop agreements with the many other countries that send workers to the country (Blank, 2011). Moreover, as shown in the Philippines' MOU with British Columbia, there is more emphasis on setting up the recruitment process than establishing mechanism for post-deployment measures to protect TFWs. Because the recruitment clauses mainly guide employers on how to find workers, this emphasis suggests that workers are of lesser interest to the two governments than employers are. At the same time, labour-sending countries such as the Philippines do not always have a strong moral ground to urge labour-receiving countries to enter into agreements to protect their overseas workers because of their own checkered records protecting them. For example, Migrante International (2009) documented a list of incidents where the Philippine government had failed to help overseas Filipino workers in distress.

However effective or ineffective they are, international agreements are only one of the means to protect the welfare of TFWs: Labour-sending and labour-receiving countries also implement specific measures within their national borders for the same purpose. 


\section{2: National Measures Taken in the Philippines}

The Philippines has adopted laws and created government departments to protect its overseas workers, including those in Canada. For example, the Migrant Workers and Overseas Filipinos Act of 1995 recognizes that Filipino workers' welfare, not their economic value to the country, is to be protected (Bach \& Solomon, 2008). Various provisions penalize illegal recruitment (Dacuycuy, 2009) and require the government to pay for return fare of any worker whose employment agency refuses to do so (Migrante International, 2009). Moreover, in early 2013, the Philippine government issued a ban on employee-paid recruitment fees ("No," 2013). Furthermore, the Absentee Voting Bill allows Filipinos workers abroad to vote in national elections, hence giving them a chance to influence national affairs and to remain connected with the country (Bach \& Solomon, 2008).

In addition to legislation, specific government departments have been set up to promote the welfare of overseas Filipino workers. First, the POEA is responsible for a number of preand post-deployment welfare issues of Filipino overseas workers, including recruiting, regulating private employment agencies, organizing pre-departure orientation sessions and liaising with foreign governments on supporting workers' rights (Dacuycuy, 2009). For example, after workers' complaints about missed salaries from a Saudi hospital, the POEA forbade their recruitment agency from operating while securing exit visas for the affected workers to leave the country (Rodriguez, 2011). Second, the Overseas Workers Welfare Administration (OWWA) provides services such as disability insurance and psychological counselling to Philippine workers abroad and operates entrepreneurship training for returned workers (OWWA, 2013). The services are provided through the Filipinos Resource Center, which is mandated by law to be 
set up in every country with more than 20,000 Filipino workers (Bach \& Solomon, 2008). All overseas workers must pay a membership fee and join the OWWA (Bach \& Solomon, 2008). Some non-migrant-specific departments also participate in securing migrant workers' welfare. As mentioned in Chapter Three, the Technical Skills and Development Authority collaborates with the POEA to design training programs to ensure the workers' marketability and suitability for the global labour market (Rodriguez, 2011). Furthermore, all Filipino diplomatic missions abroad are mandated to offer services, such as legal assistance in the event of an employment dispute, to the country’s overseas workers (De Castro, 2010).

The Philippine government also has developed a comprehensive pre-departure orientation program for workers. The session covers personal health, destination country profile, employment contracts, challenges living abroad, etc. (Asis \& Agunias, 2012). Interestingly, the government is not the sole provider of program seminars for workers - non-governmental organizations and employment agencies are also allowed to conduct their own sessions (Asis \& Agunias, 2012).

Although governmental actions such as those mentioned have contributed to the Philippines' reputation as an exemplary labour-exporting country, these measures do not guarantee a decent level of well-being for Filipinos working abroad. In fact, perhaps as a sad testimony to the failure of 20 years of labour-exporting policy in helping its workers, the Migrant Workers and Overseas Filipinos Act was developed only because the government wanted to calm public uproars over its inability to save a domestic helper from execution in Singapore (Bach \& Solomon, 2008; Migrante International, 2009). 


\section{3: Federal and Provincial Measures Taken in Canada}

As a labour-receiving country, Canada has adopted a number of policies and practices to protect the well-being of low-skilled TFWs. Under the constitution, the federal and provincial governments share the responsibilities of taking care of these workers.

Within its sphere of authority, the federal government impacts the welfare of TFWs largely through its immigration law and administrative actions by the federal ministries of Citizenship and Immigration and Employment and Social Development. Canadian law allows certain TFWs to work in the country continuously for up to four years before returning home (CIC, 2012a). Moreover, employers who fail to meet their obligations may be banned from hiring TFWs for up to two years (CIC, 2012a). These measures may help some TFWs to enjoy decent employment conditions and some stability in their income flow.

As for CIC, some of its initiatives promote the well-being of TFWs, especially those in low-skilled occupations. CIC's brochure on hiring TFWs reminds employers that some jobs only need knowledge of occupation-specific English skills and not high levels of English proficiency (CIC, 2010). Given the tendency of some Canadian employers to obtain highly-qualified TFWs for menial jobs to ensure that they are proficient in English (Thomas, 2010), this reminder may encourage employers to hire low-skilled TFWs with the right language skills for the job and the minimum government requirement instead of seeking overqualified workers.

In addition to the guide, since December 2011, workers in the LCP have been eligible for an open work permit when they apply for permanent residence, instead of waiting until the initial approval of their permanent residence as previously done (CIC, 2012a). Although not directed at the well-being of live-in caregivers during their time of service, this change may help these workers to plan for their future given the early attainment of the open work permit. 
Like CIC's (2010) guide for employers, HRSDC (2012b) has published a brochure on workers' rights for TFWs. Given its content, it appears to target workers in low-skilled occupations. The guide states that the employer cannot deport them, keep their passports or withhold portions of their wages for payment on insurance for workplace injuries. The employer also must provide breaks during the work day and ensure work safety. The amount of pay and the work hours each week should be specified in the contract. Moreover, it is the employer's responsibility to pay for their return fare and provide private health insurance until their enrollment in the provincial plan takes effect. In addition, workers can refuse dangerous job assignments for which they have no training and they can change jobs as long as the new employers have or can secure a positive LMO.

These federal government actions may help promoting the TFWs' welfare by increasing their employers' and employees' awareness of workers' rights and improving TFWs' work stability. At the same time, provinces also handle TFW-related affairs. Among the provinces, Manitoba has been one of the most enthusiastic in welcoming these workers and one of the most active in ensuring their welfare. Its treatment of TFWs can thus be used as an example of-and a model for-provincial government policy to protect the welfare of TFWs.

The Manitoba government sees TFWs as potential permanent residents and recognizes that their employment and living experiences as workers can affect their decision to stay in the province (Moss, Bucklaschuk, \& Annis, 2010). The main tool Manitoba employs to ensure the well-being of TFWs is the Worker Recruitment and Protection Act. Similar to measures in British Columbia and Alberta, this Act forbids charging TFWs recruitment fees (Allan, 2010; Byl, 2010). To ensure employers have a good history in following labour laws and use only licenced recruiters, the Act requires that they register with the province (Allan, 2010). Moreover, 
individual and business recruiters must also be licenced by the province and must be members of the Canadian Society of Immigration Consultants or of a law society in Canada (Allan, 2010). In addition, the working conditions in the contract are considered only the "minimum standard" (Allan, 2010, p. 32). The province's Labour Standards Division can investigate any violation of the contract and, in a Letter of Understanding with the federal government, the province will report any employer/recruiter transgressors to HRSDC (which is now Employment and Social Development Canada) (Allan, 2010).

In addition to this Act, Manitoba allows all TFWs to apply to its Provincial Nominee Program if they have completed six months of work and have received a full-time job offer (Allan, 2010). This provision is clearly attractive to many low-skilled TFWs: In the case of Maple Leaf Foods in Brandon, over 90\% of the TFWs in that company have applied to the PNP (Moss et al., 2010). Indeed, in 2006, among the PNP immigrants in the top 10 occupations, 22.7\% came from low-skilled occupations such as truck drivers and cooks (Manitoba Labour and Immigration, 2007, as cited in Thomas, 2010, p. 9). While these TFW-related provisions of the PNP help the province to "maximize the economic and social benefits" of having these workers (Allan, 2010, p. 30), it also has offered at least some TFWs a chance to attain permanent residence, which gives them better protection in the workplace.

Along with Manitoba's willingness to accept low-skilled workers as immigrants is the province's policy of allowing immigrant-serving agencies to offer assistance to TFWs (Moss et al., 2010). Opening settlement services to these workers encourages them to stay in the province permanently and may help retain them in their employers' companies, which minimizes recruitment costs (Moss et al., 2010). Because of this policy, TFWs can benefit from services 
that resolve many adjustment and settlement problems they have even though they are still temporary residents in Canada.

Other provinces also have taken action to ensure the welfare of TFWs. For example, British Columbia has guidelines for housing facilities for workers in the Seasonal Agricultural Worker Program (SAWP) (Tomic, Trumper, \& Aguiar, 2010). In neighbouring Alberta, a hotline for TFWs to file complaints against employers and pilot programs to offer settlement services to TFWs have been established (Byl, 2010). The province also has Employment Standards officers to review employers (Byl, 2010).

In spite of the many governmental actions initiated to protect TFWs, however, the workers still face many problems, which will be explored in the next chapter. 


\section{Chapter 5 The Well-being of Filipino Low-Skilled Temporary Foreign Workers in Canada}

Are the measures taken by the Philippine and Canadian governments effective in protecting Filipino TFWs in Canada? This chapter examines the experiences of these workers in five areas — recruitment, the correspondence between workers' skills and job requirement, abuse (both professional and personal), housing, and family separation — and argues that governmental actions to date are not adequate.

\subsection{Recruitment}

The recruitment process can involve much exploitation. Workers are often obliged to pay money to employment agencies in order to secure a position overseas. In the Philippines' case, the level of payment depends on the receiving country, with Canada being one of the most attractive destinations (while Middle East countries are at the bottom) and, thus, one of the most expensive in recruitment fees (Paul, 2011). Many low-skilled Filipinos start working at a lowtier destination to save enough money to pay for fees required for employment in countries in the higher levels (Paul, 2011). Before the Philippines banned charging TFWs recruitment fees at the beginning of 2013 ("No," 2013), the government had set one month of salary as the maximum fee that employment agencies could obtain from workers. However, these agencies often violated the law because applicants eager for a position overseas were willing to pay more than what the law prescribed-as much as four months of earnings for a 2-year contract (Martin et al., 2004).

In addition to agency fees, low-skilled Filipino TFWs are responsible for other recruitment-related expenses such as training and orientation. While it may be reasonable to charge workers for instruction and course materials, some agencies offer unnecessary training to increase their profits ("No," 2013). Furthermore, some of these agencies are allowed to conduct pre-deployment orientation sessions (Asis \& Agunias, 2012), which gives them another way to 
make money even though they often provide insufficient information to prospective TFWs about the host country and workers' rights (Migrante International, 2009). With the ban on charging workers recruitment fees, it is likely that employment agencies will devise other training schemes to protect their profits.

The problem of workers making an assortment of payments to recruiters is exacerbated by various factors. For example, many Filipino families have become dependent on remittances (Martin et al., 2004) — in fact, some even demand more financial support from the TFWs than what the workers have given (Lan, 2003)—which increases the desperation for employment abroad. Moreover, the global economic downturn in recent years has simultaneously resulted in a rise in unemployment in the Philippines and a drop in the demand for Filipino workers in foreign countries (Migrante International, 2009), making the remaining overseas positions more desirable and the workers more willing to pay high recruitment fees for them. Hence, many Filipino TFWs in Canada carry a heavy financial burden and face intense pressure to keep their jobs when they first enter the country, which can encourage them to tolerate workplace abuses in order to maintain an income flow (Oxman-Martinez et al., 2005).

Government measures are not necessarily effective in curbing the exploitation of TFWs in the recruitment process. Although the POEA handles worker-agency disputes, the slow mediation process involved sometimes leads a worker to accept a settlement offer that is not in his/her best interest (Migrante International, 2009). Moreover, even when an agency's licence is cancelled as punishment, it can easily apply for a new one (Migrante International, 2009). In addition, some Philippine government officials turn a blind eye to the operation of an illegal agency because of its connection to high-ranking officials (Piper, 2004). In Canada, because the LCP offers an opportunity for permanent residence and many TFWs can work up to four years, 
many workers rarely need to deal with dubious recruitment practices. However, these provisions may also increase Canada's attractiveness to prospective Filipino TFWs and make them more receptive to questionable schemes to recruit them to work in this country.

\subsection{Mismatch of Skills}

Recruitment is not the only area where Filipino TFWs' welfare is being diminished due to their desperation for jobs overseas: Another one is the compatibility of work-required and selfacquired skills. Some workers do not have the requisite skills to operate the equipment at a foreign workplace (Tomie, 2010); alternatively, others have education and expertise above what is required in their current work responsibilities. In the Philippines, this latter case, the "brain waste," has been known for a while (Dacuycuy, 2009, p.2). A glaring example of this is that some Filipino doctors decide to return to school to acquire nursing certification so they can work overseas as nurses (Jauregui \& Xu, 2010).

In Canada, Filipino TFWs frequently understate their qualifications in order to obtain employment in low-skilled occupations in this country (Lowe, 2010). Many participants in the LCP, in particular, have more education than the program's requirements of six months of caregiving training and high school graduation (Brickner \& Straehle, 2010; CIC, 2013c). Because many have worked as domestic helpers overseas to accumulate savings and experience prior to entry to Canada (Paul, 2011), their two years in the LCP only prolong the period of mismatch between their qualifications and their work experience. One problem with this kind of mismatching is that workers who intend to resume their professional lives upon finishing their LCP service will find it difficult to enter their previous fields (Brickner \& Straehle, 2010). Given the findings of poorer economic outcomes among new immigrants than among native-born Canadians - for example, 30-40\% lower income (Picot \& Sweetman, 2012)—obstacles to 
resume a professional life only perpetuate the problem. In addition to the LCP workers, overqualified Filipino TFWs in other low-skilled occupations can face the same problem.

The measures adopted by the Philippine and Canadian governments are not adequate to solve the problem of "brain waste." Although the POEA does support the development of training that meets the labour market needs of foreign countries and the Philippines' MOUs with western Canadian provinces oblige the latter to support training of its youth, these do not address the concerns of the overqualified workers lingering in low-skilled occupations abroad. Meanwhile, the change in CIC regulations that offers LCP alumni an earlier chance for an open work permit should help these workers find a job that is more to their liking than caregiving; however, it does not help them acquire up-to-date skills in their original professional fields.

\subsection{Abuse}

In addition to recruitment and qualification issues, abuse in the workplace can negatively affect the TFWs' well-being. Low-skilled TFWs are vulnerable to this because they have virtually no mobility in the labour market (Marsden, 2010). In addition, factors such as the limitation of the work visa to one employer, the low status of their occupations, and, for some, the requirement to live in the employer's premises may also contribute to the risk of abuse.

The Filipino live-in caregivers' experiences provide an example of this. The western world's demand for foreign domestic help is a result of women's desire to develop careers outside the home and their need to hire someone to provide childcare and perform household duties (Lan, 2003). This means that, at least for some employers, the latter kind of work-and hence, workers-is not respected as much as other career options. In addition, living with the employer can expose workers to expectations and pressure to work longer hours than what their 
contracts prescribe. Finally, coming from a foreign country, not all live-in caregivers understand Canadian law regarding working conditions and abuse.

Research has, indeed, shown that these problems exist. For example, a survey of Filipino workers in the LCP in the Montreal area has found that $43 \%$ of the respondents had worked overtime without getting extra payments and $16 \%$ were the victims of physical abuse and neglect (PINAY (2008), as cited in Brickner \& Straehle, 2010, p. 314-315). A newspaper in Montreal reported incidents of employers using racial slurs against live-in caregivers and ignoring their needs, including one case where a worker was not provided with food at an evening event (Devine, 2004). Some families also attempted to get free overtime work in a seemingly noncoercive way: They used the harmonious caregiver-child relationship as an excuse to ask the worker to work extra hours or days (Lan, 2003). Unpaid overtime work not only violates contracts but it also leaves the LCP workers with little time to take care of their own health. Due to a fear of losing of their jobs, some live-in caregivers continue to work even when they are sick (Preibisch \& Hennebry, 2011).

In another study, Welsh, Carr, MacQuarrie, \& Huntley (2006) found that some Filipino live-in caregivers who participated in a focus group showed an ambiguous understanding of sexual harassment. Some justified the employer's lewd actions by, for example, attributing them to senility. The home as a workplace can be a factor because it is not always easy to determine what behaviour is acceptable in a private dwelling (Welsh et al., 2006). Nevertheless, regardless of how the respondents interpreted the sexual harassment experience, they acknowledged that, as non-citizens needing an income, they were powerless to change the situation (Welsh et al., 2006). Apart from male employers, live-in caregivers can also experience problems with the female head of household. While working outside the home, some women may fear the loss of 
respect as the mother and the wife in the house because the caregivers are performing their roles, and they can be hostile towards these workers (Ladegaard, 2012).

Given the continued existence of abuse, governmental actions to protect low-skilled TFWs in their work settings clearly are not adequate. In fact, in the Philippines' case, its labourexporting policy has been characterized uncharitably by a worker advocacy group as "the breeding ground for rights abuse" (Migrante International, 2009, p. 2). This group argues that the government does not care about Filipino overseas workers and does not have the resources or training to help them. For example, although the Philippines' foreign missions are responsible for providing legal assistance, a Filipina accused of killing an Arab in Saudi Arabia received no such help and was only given a translator from the Philippine consulate - she was subsequently convicted of murder and was beheaded (Migrante International, 2009). Filipino workers overseas have also complained about the government's lack of response when they face problems with non-payment of salary (Rodriguez, 2011). In addition, although the Migrant Workers and Overseas Filipinos Act of 1995 requires the government to advance payment for return airfare when an agency does not do so, the government sometimes asks the relatives to buy the ticket instead (Migrante International, 2009).

As for Canada, the enforcement of immigration, labour and even human rights law clearly has not been able to prevent the abuse of TFWs. Frequently any investigation of violation of employment standards or human rights requires the affected worker to report the offence and many TFWs may not know the law or dare to complain because they fear losing their jobs (Byl, 2010). 


\subsection{Housing}

As mentioned, one reason that low-skilled TFWs are vulnerable to abuse by Canadian employers is the practice that the employers provide or assist with finding accommodation to low-skilled TFWs. Concerns over this rule have been focused on the workers' privacy (Brickner \& Straehle, 2010), exposure to abuse (Ladegaard, 2012) and housing conditions and costs (Alberta Federation of Labour [AFL], 2010; Tomie, 2010). A good example of this is, once again, Filipinas working in the LCP.

Living in an employer's home is not easy. Feelings of loneliness and isolation can increase mental health risks over time (Oxman-Martinez et al., 2005). Moreover, as shown in the Montreal survey mentioned earlier, the inability to leave the workplace at the end of the work day often results in the live-in caregivers performing unpaid overtime work (PINAY (2008), as cited in Brickner \& Straehle, 2010, p. 314).

Governmental actions are not effective in ensuring decent housing conditions for lowskilled TFWs. Overseas Filipino workers have complained that the Philippine government does not help them find alternative residences when they live in a filthy environment (Rodriguez, 2011). Indeed, the government itself has admitted to the UN Committee on Migrant Workers that it does not have means to monitor housing conditions of Filipinos working in foreign countries (Migrante International, 2009). Despite the Canadian federal government's leading role in admitting foreign workers, it has no guidelines for migrant workers' housing (Hennebry, 2010). Provinces and municipalities have tenant laws but many TFWs do not know their rights as tenants (Byl, 2010). 


\subsection{Family Separation}

In addition to housing, low-skilled Filipino TFWs do not receive much governmental support dealing with family separation. Long-term separation can negatively affect family stability (Dacuycuy, 2009). Family members develop different interests and outlooks when living apart from each other. Although workers with access to a telephone or Internet can maintain contact with their families and even help their children in their school assignments (Madianou, 2012), the contact lacks the face-to-face intimacy. Furthermore, some frontline workers with TFWs have argued that such separation can lead to a sense of isolation and alcoholism (Standing Committee on Citizenship and Immigration, 2009). In addition, in a patriarchal society such as the Philippines, some men whose wives are working abroad and are, thus, assuming the role of the breadwinner engage in extramarital affairs to assert their own masculinity (Lan, 2003). Even when the family reunites during the worker's leave or at the end of a contract, family members may feel like strangers to one another (Moss et al., 2010; Pratt, 2006), so much as that, for some LCP alumni, their eventual unification with their family in Canada upon receiving permanent residence is marked by conflicts among members (Pratt, 2006).

Government policy does not promote the well-being of low-skilled TFWs when it comes to family separation. Canadian law does not permit the spouses and children of workers in the LCP and the Low-Skilled Pilot to obtain work/study permits (Depatie-Pelletier, 2010), which makes reunion in Canada impossible for many low-skilled TFWs because of the financial burden of housing and feeding them. Even though the right to family reunion and education of their children is recognized in the United Nations' Convention on the Protection of the Rights of Migrant Workers and Members of their Families (De Castro, 2010), the document means little in 
terms of the welfare of TFWs because Canada has not ratified it. At the same time, even though the Philippines is one of the signatories, it cannot do anything other than, if it wants to, press for legislative changes in Canada. Hence, in the case of Filipino TFWs in low-skilled occupations in Canada, family separation is actually an example of the futility of pursuing international agreements as a means of protecting migrant workers.

\subsection{Other Low-Skilled Temporary Foreign Workers}

The five areas discussed in this section demonstrate the inadequacy of government actions to protect workers' well-being. They are certainly not exhaustive of issues concerning the welfare of low-skilled Filipino TFWs in Canada. These problems are also not exclusive to this group-and only highlight Canada's failure to support low-skilled TFWs in general. For example, exploitative hiring ploys have forced TFWs to pay recruitment fees even when their agencies operate in Canadian jurisdictions that forbid such practices, such as British Columbia and Alberta: To avoid legal action against them, sometimes agencies force workers to pay the money before leaving their countries and sometimes workers pay cash when they receive their salary in Canada (Byl, 2010). Second, the mismatch between TFWs' training and their job tasks may be widespread among TFWs in low-skilled occupations. In 2006, among non-permanent residents, $85 \%$ of the housekeepers and $55 \%$ of the cleaners as well as $30 \%$ of male truck drivers and $78.7 \%$ of the female caregivers of children had received some tertiary education (Thomas, 2010). Moreover, $91.2 \%$ of TFWs in 2006 could speak English, which suggests the attainment of high levels of education in sending countries (Thomas, 2010). The mismatch of skills can also involve under-preparation for jobs. For example, a survey of 576 TFWs in the SAWP revealed that $62 \%$ of the Mexicans had not received training in work safety and half of the respondents did not use safety goggles or gloves when handling chemicals (Hennebry, 2010). Third, abuse 
happens to other low-skilled TFWs as well. Some workers are given a wage lower than the one promised in the contract (Byl, 2010) and TFWs are often expected to work extra time without added compensation (AFL, 2010). In addition, employers often change TFWs' job descriptions (AFL, 2010), for example, sometimes assigning workers to sites in another province ("Foreign," 2007). Perhaps especially difficult for workers with high hopes of settling in Canada is that some employers and recruitment agencies give them incorrect information about their immigration prospects in order to lure them to work in low-skilled occupations in Canada (AFL, 2010). Fourth, many low-skilled TFWs working in Canada also experience housing problems. SAWP participants are required to live in employer-provided accommodation and thus can find the same privacy and exploitation problems that live-in caregivers experience. Moreover, because they are sometimes located close to farm chemicals, their living quarters can be dangerous (Tomic et al., 2010). A survey in southern Ontario indeed found that a quarter of SAWP workers believed that their housing conditions jeopardized their health (Hennebry, 2010). Finally, the problems associated with family separation are not limited to low-skilled TFWs alone. The length of separation can range from eight months for SAWP workers (Employment and Social Development Canada, 2013) to four years for many other TFWs.

Because multiple federal and provincial government departments are involved in the TFW programs, it is often left to the employers, who may not have the knowledge or the incentive, to advise the workers of their rights and immigration prospects, etc. (Nakache, 2010).

\subsection{Citizenship Rights}

One issue that underlines these challenges to low-skilled TFWs' well-being is citizenship. Citizenship can be seen as a form of capital (Bauder, 2008). It confers certain rights to holders of this status that help them pursue other forms of capital. For example, scholarships reserved 
exclusively for permanent residents and citizens enable them to acquire the human capital of higher education easier than people without the status. Depending on their immigration status, non-citizens in many industrialized countries are entitled to some, but not all, of these rights. Permanent residents have almost all the rights as citizens while illegal migrants have practically no guaranteed rights (Ruhs, 2012). Given their status, low-skilled TFWs in Canada are susceptible to the problems in the five areas mentioned and are incapable of resolving them because they do not have full rights as citizens or even permanent residents in the country (Seol, 2005). Although they enjoy some of the freedoms accorded to citizens, they face restrictions in a number of activities, including their length of stay in the country, the choice of employers, and, for some, their place of accommodation. As temporary residents of the receiving country, they have limited influence on their well-being. Hence, as stated in the introduction, these workers are, in a way, second-class residents.

TFWs are citizens of their home countries. However, in the context of their welfare as overseas workers, citizenship in the sending country may actually exacerbate the problems that arise from not having full citizenship rights in the receiving country. As citizens of the sending country, TFWs may have an obligation to support their families and their country. In the Philippines' case, there are actually government requirements that Filipinos working abroad send remittances of 50\%-70\% of income (Migrante International, 2009) and the government and media promote a folk image of the filial daughter who supports the country with money (Barber, 2000). To fulfill such expectations, many TFWs are willing to tolerate abuse and family separation. Hence, it is their obligations as citizens of their country of origin, in addition to their lack of rights as non-citizens in a foreign country, that expose TFWs to risks of poor well-being while working overseas. 
With this in mind, some suggestions to improve the low-skilled TFWs' well-being are made in the next chapter, including expanded rights for these workers and appeal for a pathway to permanent residence. 


\section{Chapter 6 Improving Low-Skilled Temporary Foreign Workers' Welfare}

Some suggestions to deal with the five areas of challenges in the previous chapter are made here. In addition, two further suggestions are proposed to tackle the issues of the inadequacy of the government's role and the importance of citizenship rights in the well-being of TFWs.

\section{1: Suggestions for Specific Areas of Welfare}

As noted in the last two chapters, employment agencies in both sending and receiving countries often can find ways to exploit migrant workers, such as charging cash payments or training fees to skirt any requirement that sets or forbids employee-paid recruitment fees. At the same time, given their desperation for a job abroad, many TFWs are unwilling to report any misconduct in the recruitment process. Consequently, three recommendations are made here. First, Canadian provinces should adopt Manitoba's law to register recruiters and employers (Allan, 2010). Violators of recruitment laws will have to repay any illegal fees charged to TFWs and may be de-registered after the current contractual period. Second, accurate income and costof-living information should be provided in pre-departure sessions in the home country so any prospective workers can decide if working abroad is worth the costs. Third, because recruitment agencies in the Philippines may have a conflict of interest if they conduct those sessions (Asis \& Agunios, 2012)—for example, misleading workers with rosy information about working in Canada-their involvement in orientations should be stopped.

Second, to alleviate the problem of the mismatch of qualifications between workers and job tasks, three suggestions are made here. First, the sending countries can tailor their education policy to support training programs for the overseas labour market if the deployment of workers abroad is a long-term economic strategy. Second, they can develop industrial and trade policies 
that invite investment in advanced technological fields to promote the employment of homegrown professionals in the local labour market. Third, in a receiving country like Canada, where some TFWs in low-skilled occupations (e.g., those in Manitoba and LCP workers) are eligible for permanent residence after a period of service, the host government can offer financial support to workers with prior relevant qualifications to take refresher courses that prepare them to reenter their professions.

Third, to tackle the issue of abuse, two suggestions are made. First, following a similar call for changes in the LCP (Brickner \& Straehle, 2010) and in the TFW program (Standing Committee on Citizenship and Immigration, 2009), the work visa for low-skilled TFWs should be sector-specific instead of employer-specific. This proposal would allow TFWs to leave an abusive employer while keeping the same amount of workers in the specific sector that needs TFWs. It would also help prospective employers to secure the service of unemployed TFWs immediately (Standing Committee on Citizenship and Immigration, 2009). Second, TFWs should be made aware of their rights and the process to report any violations of these rights. Because the provinces are responsible for working conditions and because many low-skilled TFWs are not proficient in English/French, provincial governments should provide relevant information in languages of the main TFW source countries such as Tagalog and Spanish when TFWs arrive at the port of entry. Similarly, the federal government should mandate that employment contracts with low-skilled TFWs be translated into the workers' language (Tomie, 2010).

Fourth, one suggestion about TFWs' housing is made here: The live-in requirement in the LCP (and SAWP) should be made optional for workers. Some researchers and a parliamentary committee want the elimination of the requirement to protect the workers (Brickner \& Straehle, 
2010; Standing Committee on Citizenship and Immigration, 2009) but many TFWs may prefer the employer's residence for financial or convenience reasons. Those who choose to live outside the employer's home should be given a full salary with no deduction for room and board (as in the LCP now) because the employer is not responsible for their housing. This suggestion actually can also benefit prospective Canadian employers: Those who want live-in caregivers but do not have a suitable place for them would be able to hire them.

As for family separation, two suggestions are proposed here. First employer-provided housing must have a telephone (Standing Committee on Citizenship and Immigration, 2009) or computer with limited Internet access. Second, immediate family members should enjoy priority in tourist visa applications. Although physical separation for months would remain a reality, both suggestions should facilitate TFWs' contact with family members.

Overall, as shown by the last point, suggestions to improve specific areas may be limited in scope and effectiveness because each one does have drawbacks-for example, workers' refusal to report abusive employers even when they know their rights. What may be more effective in the sense of dealing with a broad spectrum of challenges and effecting a deep impact on TFWs' lives and livelihood are the use of immigrant-serving agencies and other non-profit organizations in civil society and the expansion of rights to protect these workers' well-being.

\section{2: Civil Society}

Direct governmental actions cannot always help TFWs because of factors such as their focus (for example, on recruitment) and the workers' preference (for example, using informal support networks). Hence, civil society, including immigrant-serving agencies, immigrant and local communities, and employers, should be involved and supported to protect TFWs' wellbeing. Many members of civil society have direct experiences with TFWs and their knowledge 
of different cultures and immigrant services can be tailored to meet the immediate needs of the workers.

Immigrant-serving agencies, in particular, have expertise to help newcomers. Many of the low-skilled TFWs' needs are not different from those of other new immigrants: housing, workplace disputes, language barriers, transportation problems, etc. Serving them, thus, requires no major changes in the agencies other than expanded capacity. This can be achieved with government funding. Currently, although most low-skilled TFWs are not eligible for permanent residence, some of them have already sought information and employment assistance from these agencies even when the latter have no mandate to serve them ("Foreign," 2007). This kind of "under-the-table" assistance diverts the resources from serving people with official immigration status ("Foreign," 2007). Thus, to protect the well-being of TFWs and others, the federal and provincial governments should start funding settlement services specifically for them. If, as Manitoba has done, these workers are seen as potential immigrants who can continue to contribute to the Canadian economy, supporting these services to them throughout their stay can be important and beneficial to Canada.

In addition, immigrant diasporas in Canada can be encouraged to help TFWs. Some groups have been providing counselling or legal services to TFWs (for example, Pinay in Montreal (Tungohan, 2012)) and their efforts can be supported with some government funding. Moreover, other organizations can be recruited as well. Business associations can offer networking sessions, ethnic churches can host social activities, and language schools can provide volunteer opportunities. One advantage that diasporas have over some immigrant-serving agencies and other mainstream organizations is that the former is proficient in the workers' mother tongue and cultural subtleties such that workers may feel comfortable seeking or 
receiving help. Diasporas' potential to help TFWs can be large. In the case of the Philippines, for example, about 384,000 respondents in the 2011 Census identified Tagalog as their mother tongue (Statistics Canada, 2013). Some Filipino-Canadians have been temporary workers themselves, and many may understand the challenges the TFWs face and may be able to offer appropriate support.

Mainstream organizations in areas where TFWs work can likewise offer services. Based on a series of discussion among stakeholders concerned with the welfare of Caribbean workers in Canada, Gibb (2010) has suggested that community groups should be engaged to provide some services to TFWs - for example, local religious settings where workers visit can be enlisted to offer information on health and migrant services because of their accessibility. Moreover, as in the case of diaspora groups mentioned above, some labour unions, such as United Food and Commercial Workers Union and United Steel Workers have been helping TFWs with language and dental services (in addition to advocacy) (Flecker, 2010): Government funding can be made available for similar direct-service programs by established groups.

This idea of local support can also be extended to the workplace. Tax incentives can be provided to employers who are willing to implement various measures to protect the well-being of their TFWs beyond the minimum expectations prescribed in the law. Maple Leaf Foods in Brandon, Manitoba, is a good example of how a business can take extra steps to help its TFWs settle in their jobs and new community (Watt, Krywulak \& Kitagawa, 2008). The company started its own recruitment office in 2007 with the aim of retaining TFWs for long terms (Watt et al., 2008). Its staff meets with potential TFWs in their home countries to assess their fit with the company, assessing such factors as language and health, education and experience, and PNP suitability (Watt et al., 2008). The company pays for all recruitment and transportation costs, 
finds housing and pays the rent for the first month (Watt et al., 2008). The company also has negotiated and subsidized new bus routes and schedules to suit its employees and has offered English as Additional Language training to TFWs and information sessions on the PNP for workers after 6 months of employment (Watt et al., 2008). Given the high retention rate of workers who have been accepted to the PNP-73 out of 74 in 2008 — other businesses can benefit from adopting at least some of Maple Leaf Foods' measures (Watt et al., 2008). In addition, employers can encourage Canadian employees to provide support, such as mentoring, to TFWs (Tomie, 2010).

Overall, civil society can tackle many challenges to the well-being of low-skilled TFWs because of the variety of players, their cultural knowledge and organizations that are accessible to TFWs. Immigrant-serving agencies, members of the diaspora and local communities, labour unions and employers can help workers with issues in the five problem areas mentioned as well as other obstacles such as accessing information on immigration or finding cultural events.

\section{3: Permanent Residence and Labour Market Rights}

As mentioned, the rights of low-skilled TFWs fall short of what is granted to permanent residents, rendering them at increased risk of and limited protection against exploitation and various work and living problems. It is proposed here that TFWs, both low-skilled and highskilled, be eligible for permanent residence after fulfilling their contractual commitment in Canada and should enjoy most labour market rights as Canadian citizens during their period of service.

The foundation of the current low-skilled TFW programs is economics: Workers are needed to fill jobs that Canadians do not want (Marsden, 2012). These workers are seen as not bringing anything other than their willingness and abilities to toil temporarily in the workplace 
(Marsden, 2012). Even when such a view on the economic benefits of having foreign labour is accepted, Marsden (2012) argues that low-skilled TFWs should be given the right to permanent residence because the jobs they are performing have a long-term dependence on foreign workers: Permanent labour market needs justify permanent residence rights. Given Canadian immigration policy's increasing emphasis on immigrants' economic contributions to the country (Douglas \& Go, 2013), Marsden's suggestion is, indeed, consistent with the direction Canada has been going and is echoed by both labour advocates (Flecker, 2010) and a parliamentary committee (Standing Committee on Citizenship and Immigration, 2009).

Marsden's position can be supported on a couple of grounds. First, Manitoba's experience accepting low-skilled TFWs in its Provincial Nominee Program suggests that the need for these workers is not limited to the duration that low-skilled TFWs are allowed to work. Second, many of the low-skilled TFWs who would apply and receive permanent residence likely would not change jobs immediately due to their low levels of qualifications and so granting eligibility for permanent residence to low-skilled workers may simply help employers to reduce their hiring and training costs for new TFWs over time. As Maple Leaf Foods' experience indicates, a comprehensive package of support for workers from their initial arrival to the eventual attainment of permanent residence can keep TFW-turned-permanent residents' loyalty to an employer (Watt et al., 2008).

New rules granting eligibility of permanent residence to all TFWs could follow the model of the LCP. After two years—or, depending on the occupations, another length of time —of employment, the worker would be eligible for permanent residence for the whole immediate family. While awaiting a decision, he/she will be issued an open work permit. Once the 
application is approved, the family can join the worker in Canada. This suggestion is, indeed, similar to one proposed by the Standing Committee on Citizenship and Immigration (2009).

It may be argued that the prospect of permanent residence after a period of service might encourage some TFWs to tolerate any exploitative treatment in order to wait until their employment obligations are finished (Tungohan, 2012). This is why TFWs should be granted most of the labour market rights that Canadian citizens enjoy-for example, the right to union membership and collective bargaining, which are not available to many TFWs in Canada at this time (Marsden, 2012). One right that can be excluded, however, is that of changing sectors of employment. Given that most TFWs are admitted to fulfill immediate labour shortage of the country, letting these workers move from one sector to another will leave some businesses in need of workers short of employees. In this case, as mentioned in Section 6.1, a sector-specific work visa, instead of the current employer-specific one, can be issued so the TFWs can still find a new employer in the event of any unpleasant experience with the current one without hurting the labour supply in the sector for which they are recruited in the first place.

The specific rights to be included or excluded can be determined between the federal and provincial governments. In this case, a first ministers' conference could be held to develop a consistent nationwide approach to TFWs, including labour market rights (e.g., length of stay upon unemployment), social benefits for workers, and language criteria for TFWs' application for permanent residence through their low-skilled status.

There will be dissenting views on these two proposals. For example, some have argued that TFWs should have the full range of rights in the labour market as Canadians because the values of human rights that Canada espouses are intended to prevent any inequality among people in the country regardless of their formal citizenship (Tungohan, 2012). Similarly, some 
have pressed for the elimination of the TFW programs such that foreign workers should come in as permanent residents with equal rights (Byl, 2010). However, the current suggestions of granting permanent residence rights after a period of service and honouring most labour market rights during that period may benefit the most people, offering Canada a rapid injection of workers to fill labour shortage, Canadian employers some reduction in hiring costs, and foreign workers some protection from exploitative practices. These actions actually would align Canada's TFW policy toward its purported position on human rights. Moreover, conceptually, it is easy to reconcile the granting of residence rights to TFWs with the restricting of their rights prior to permanent residence: After all, "migrant rights [can be seen] as a subset of citizenship rights" (Ruhs, 2012, p. 1287) and the proposal here is to expand the subset to the maximum before any further movement will harm the economic benefits Canada receives from having TFWs. 


\section{Chapter 7 Conclusion}

Labour migration does not have to be a disadvantageous affair. Workers, their families, their employers and the national economies of both the sending and receiving countries can benefit from this activity. The key is how to maximize benefits while minimizing disadvantages.

Many low-skilled Filipino TFWs in Canada have experienced exploitation in the recruitment process, a mismatch between their skills and job requirements, abuse by the employers, as well as housing and family problems. It is clear that even an acclaimed sending country like the Philippines and a liberal receiving country like Canada do not adequately protect migrant workers.

However, there are ways to improve the situation. As stated in this paper, the governments can enact a number of measures to deal with specific problems, support the work of civil society to help workers, and change immigration rules to grant permanent residence and expanded rights for low-skilled TFWs. Implementing these suggestions would benefit not only TFWs but also Canadian employers and Canada as a whole. Motivated workers who stay in the same industry after obtaining their permanent residence reduce the recruitment and training costs for employers. As in the case of Maple Leaf Foods, having a stable TFW workforce also ensures product quality and safety (Watt et al., 2008). The locales where TFWs are staying permanently also benefit with an enlarged tax base and attract investment in new businesses (including ethnic restaurants) (Watt et al., 2008).

Some of these suggestions may be useful for other labour-exporting and labour-importing countries as well. Learning the best practices and avoiding the mistakes of other countries is important because of the global economy's increasing dependence on migrant workers. In fact, given that Canada is dependent on TFWs more and more- 4.4 million job openings will be 
available in the next decade (Kustec, 2012), some of which will be filled by TFWs-and the Philippines will continue to export workers, both countries can learn from others as well. For example, low-skilled migrant workers in Singapore are largely satisfied with their work and environment in terms of salary, work safety information, and work-related training (Government of Singapore, 2011; Government of Singapore \& Migrant Workers' Centre, 2012). Perhaps, then, both Canada and the Philippines can emulate what the island country has done that is helpful and satisfying to workers, such as ensuring proper training.

It is ironic that low-skilled TFWs are protected by home and host governments, but they often have less protection than local workers. It is hoped that the adoption of some of the suggestions in this paper may improve their welfare from the point of recruitment in the sending country to the time of (possible) residence in the receiving country. 


\section{References}

Alberta Federation of Labour. (2010). Exploitation of foreign workers continues unabated. Retrieved from http://www.afl.org/index.php/Temporary-Foreign-Workers/overview.html

Allan, N. (2010). Foreign worker recruitment and protection: The role of Manitoba's Worker Recruitment and Protection Act. Canadian Issues, 29-32. Retrieved from http://canada.metropolis.net/pdfs/cdn_issues_CITC_mar10.pdf

Asis, M. M. B., \& Agunios, D. R. (2012). Strengthening pre-departure orientation programmes in Indonesia, Nepal, and the Philippines. Bangkok and Washington, DC: International Organization for Migration and Migration Policy Institute. Retrieved from http://www.migrationpolicy.org/pubs/PredepartureOrientation.pdf

Bach, J., \& Solomon, M. S. (2008). Labors of globalization: Emergent state responses. New Global Studies, 2, 1-19. doi: 10.2202/1940-0004.1025

Barber, P. G. (2000). Agency in Philippine women's labour migration and provisional diaspora. Women's Studies Individual Forum, 23, 399-411.

Bauder (2008). Citizenship as capital: The distinction of migrant labor. Alternatives, 33, 315333.

Blank, N. R. (2011). Making migration policy: Reflections on the Philippines' bilateral labor agreement. Asian Politics \& Policy, 3, 185-205.

Blouin, C. (2005). Liberalizing the movement of services suppliers: Lessons from the Canadian experience with temporary worker programs. Journal of World Trade, 39, 881-895.

Brickner, R. K., \& Straehle, C. (2010). The missing link: Gender, immigration policy and the Live-In caregiver Program in Canada. Policy and Society, 29, 309-320. doi: 10.1016/j.polsoc.2010.09.004 
Byl, Y. (2010). Temporary foreign workers in Canada: A disposable workforce? Canadian Issues, 96-98. Retrieved from http://canada.metropolis.net/pdfs/cdn_issues_CITC_mar10.pdf

Citizenship and Immigration Canada. (2010). Employer's roadmap to hiring and retaining internationally trained workers (Cat. No.: Ci4-16/2010E-PDF)

Citizenship and Immigration Canada. (2012a). Annual report to Parliament, 2012 - section 2: Managing permanent immigration and temporary migration. Retrieved from http://www.cic.gc.ca/english/resources/publications/annual-report-2012/section2.asp

Citizenship and Immigration Canada. (2012b). Become a permanent resident - live-in caregivers. Retrieved July 11, 2013, from http://www.cic.gc.ca/english/work/caregiver/permanent_resident.asp\#require

Citizenship and Immigration Canada. (2012c). Canada - facts and figures: Immigration overview - permanent and temporary residents 2011. Retrieved from http://www.cic.gc.ca/english/pdf/research-stats/facts2011.pdf

Citizenship and Immigration Canada. (2013a). Canada-Temporary foreign workers present on December $1^{\text {st }}$ by province or territory and urban area, 2008-2012. Retrieved from http://www.cic.gc.ca/english/resources/statistics/facts1012-preliminary/04.asp

Citizenship and Immigration Canada. (2013b). Canada-Total entries of temporary foreign workers by province or territory and urban area, 2008-2012. Retrieved from http://www.cic.gc.ca/english/resources/statistics/facts1012-preliminary/03.asp

Citizenship and Immigration Canada. (2013c). Determine your eligibility: Live-in caregivers. Retrieved August 10, 2013, from http://www.cic.gc.ca/english/work/caregiver/applywho.asp 
Commission of Filipinos Overseas. (2013). Stock estimate of overseas Filipinos as of December 2011. Retrieved from www.cfo.gov.ph/images/stories/pdf/2011_Stock_Estimate_of_Filipinos_overseas.pdf

Dacuycuy, L. B. (2009). Best practices in fostering migration opportunities: Do they work? ILO Asian Regional Programme on Governance of Labour Migration Working Paper No. 22.

De Castro, R. C. (2010). Weakness and gambits in Philippine foreign policy in the twenty-first century. Pacific Affairs, 83, 697-717.

Department of Labor and Employment of the Government of the Republic of the Philippines and Department of Advanced Education and Employment of the Province of Saskatchewan of Canada. (2006). Memorandum of Understanding between the Department of Labor and Employment of the Government of the Republic of the Philippines and Her Majesty the Queen in the Right of the Province of Saskatchewan as Represented by the Minister Responsible for Immigration and the Minister of Advanced Education and Employment concerning the Cooperation in the Fields of Labour, Employment and Human Resource Development.

Department of Labor and Employment of the Republic of the Philippines and Ministry of Employment and Immigration of Alberta. (2008). Memorandum of Understanding between the Department of Labor and Employment of the Republic of the Philippines and Ministry of Employment and Immigration of Alberta concerning Cooperation in Human Resource Deployment and Development.

Depatie-Pelletier, E. (2010). Restrictions on rights and freedoms of low-skilled temporary foreign workers. Canadian Issues, 64-67. Retrieved from http://canada.metropolis.net/pdfs/cdn_issues_CITC_mar10.pdf 
Devine, S. (March 2004). Respect for nannies: Live-in caregivers in Montreal. Our Times, 33.

Dimaya, R. M., McEwen, M. K., Curry, L. A., \& Bradley, E. H. (2012). Managing health worker migration: A qualitative study of the Philippine response to nurse brain drain. Human Resources for Health, 10 (47). doi: 10.1186/1478-4491-10-47

Douglas, D., \& Go, A. Y.-Y. (2013, August 10). Immigration is about people, not economics. The Toronto Star. Retrieved from http://www.thestar.com/opinion/commentary/2013/08/10/immigration_is_about_people not_economics.html

Employment and Social Development Canada. (2013). Hiring seasonal agricultural workers. Retrieved from http://www.hrsdc.gc.ca/eng/jobs/foreign_workers/agriculture/seasonal/index.shtml

Fitzgerald, D. (2006). Inside the sending state: The politics of Mexican emigration control. IMR, 40, 259-293. doi: 10.1111/j.1747-7329.2006.00017.x

Flecker, K. (2010). Building a disposable workforce through temporary migration policy. Canadian Issues, 99-103. Retrieved from http://canada.metropolis.net/pdfs/cdn_issues_CITC_mar10.pdf

Foreign worker woes: A federal program is providing desperately needed labour for Alberta employers - but at a severe price for many workers (2007, July 1). Calgary Herald, pp. B1. Retrieved from http://www/afl.org/index.php/AFL-in-the News/foreign worker woes a federal program is providing desperately needed labour for Alberta employers but at a severe price for many workers.html

Gibb, H. (2010). Missing from Temporary Foreign Worker Programs: Gender-sensitive 
approaches. Canadian Issues, 94-95. Retrieved from

http://canada.metropolis.net/pdfs/cdn_issues_CITC_mar10.pdf

Goldring, L. (2010). Temporary worker programs as precarious status: Implications for citizenship, inclusion, nation building in Canada. Canadian Issues, 50-54. Retrieved from http://canada.metropolis.net/pdfs/cdn_issues_CITC_mar10.pdf

Government of British Columbia and Government of the Philippines. (2008). Memorandum of Understanding between the Department of Labor and Employment of the Republic of the Philippines and Ministry of Economic Development of the Government of British Columbia, Canada concerning Co-operation in Human Resource Deployment and Development.

Government of Singapore. (2011). FDW and FDW employer study 2010: Report on findings. Retrieved from http://www.mom.gov.sg/Documents/statisticspublications/Report\%20for\%20MOM\%20FDW\%20and\%20FDW\%20Employer\%20Stu dy\%202010.pdf

Government of Singapore \& Migrant Workers' Centre. (2012). Foreign worker (FW) study 2011: Report on findings. Retrieved from http://www.mom.gov.sg/Documents/statisticspublications/MOM-and-MWC-FW-survey.pdf

Government of the Philippines and Government of Manitoba, Canada. (2008). Memorandum of 
Understanding between the Department of Labor and Employment of the Republic of the Philippines and Ministry of Labour and Immigration of the Government of Manitoba, Canada concerning: Co-operation in Human Resource Deployment and Development.

Hennebry, J. (2010). Not just a few bad apples: Vulnerability, health and temporary migration in Canada. Canadian Issues, 73-77. Retrieved from http://canada.metropolis.net/pdfs/cdn_issues_CITC_mar10.pdf

Human Resources and Skills Development Canada. (2012a). National Occupational Classification Matrix 2011. Retrieved from http://www5.hrsdc.gc.ca/NOC/English/NOC/2011/pdf/Matrix.pdf

Human Resources and Skills Development Canada. (2012b). Temporary foreign workers: Your rights are protected. Retrieved from http://www12.hrsdc.gc.ca

Human Resources and Skills Development Canada. (2013). Labour Market Opinion (LMO) Statistics - Annual Statistics 2012. Retrieved from http://www.hrsdc.gc.ca/eng/jobs/foreign_workers/lmo_statistics/annual2012/shtml\#h2.10 International Labour Organization. (2012a). C097 - Migration for Employment Convention (Revised), 1949 (No. 97). Retrieved from http://www.ilo.org/dyn/normlex/en/f?p=NORMLEXPUB:12100:0::NO:12100:P12100_I NSTRUMENT_ID:312242:NO

International Labour Organization. (2012b). C143 - Migrant Workers (Supplementary Provisions) Convention, 1975 (No. 143). Retrieved from http://www.ilo.org/dyn/normlex/en/f?p=NORMLEXPUB:12100:0::NO:12100:P12100_I NSTRUMENT_ID:312288:NO

International Labour Organization. (2012c). Up-to-date conventions not ratified by Canada. 
Retrieved July 10, 2013, from

http://www.ilo.org/dyn/normlex/en/f?p=1000:11210:0::NO:11210:P11210_COUNTRY_I

$\underline{\mathrm{D}: 102582}$

Jauregui, A. B., \& Xu, Y. (2010). Transition into practice: Experiences of Filipino doctor-turned nurse practitioners. Journal of Transcultural Nursing, 21, 257-264. doi:

$10.1177 / 1043659609358787$

Kelley, N., \& Trebilcock, M. (2010). The making of the mosaic: A history of Canadian immigration history. Toronto: University of Toronto Press.

Kustec, S. (2012). The role of migrant labour supply in the Canadian labour market. Citizenship and Immigration Canada Ci4-93/2012E-PDF (Ref. No.: RR20120705). Retrieved from http://www.cic.gc.ca/english/resources/research/2012-

migrant/documents/pdf/migrant2012-eng.pdf

Ladegaard, H. J. (2012). The discourse of powerlessness and repression: Identity construction in domestic helper narratives. Journal of Sociolinguistics, 16, 450-482.

Lan, P.-c. (2003). Maid or madam? Filipina migrant workers and the continuity of domestic labor. Gender \& Society, 17, 187-208. doi: 10.1177/0891243202250730

Lowe, S. J. (July 2012). Transitioning temporary foreign workers to permanent residents: A case for better foreign credential recognition. CERIS Working Paper No. 91 (Series Editor: M. A. Ali). Toronto: CERIS - The Ontario Metropolis Centre.

MacDonald, E., \& Cholewinski, R. (2007). The migrant workers convention in Europe: Obstacles to the ratification of the International Convention on the Rights of All Migrant Workers and Their Families: EU/EEA perspectives. Paris: United Nations Educational, 
Scientific and Cultural Organization. Retrieved from http://unesdoc.unesco.org/images/0015/001525/152537E.pdf

Madianou, M. (2012). Migration and the accentuated ambivalence of motherhood: The role of ICTs in Filipino transnational families. Global Networks, 12, 277-295.

Marsden, S. (2012). The new precariousness: Temporary migrants and the law in Canada. Canadian Journal of Law and Society, 27, 209-229. doi:10.3138/cjils.27.2.209

Martin, P., Abella, M., \& Midgley, E. (2004). Best practices to manage migration: The Philippines. International Migration Review, 38, 1544-1559.

Migrante International. (2009). Initial Statement of Migrante International to the United Nations Committee on Migrant Workers. Retrieved from http://www2.ohchr.org/english/bodies/cmw/docs/ngos/Migrante_Int_Philippines_10.pdf

Migrante International. (2013). Our history. Retrieved from http://migranteinternational.org/?page_id=7

Moss, A., Bucklaschuk, J., \& Annis, R. C. (2010). Small places, big changes: Temporary migration, immigration and family reunification. Canadian Issues, 33-36. Retrieved from http://canada.metropolis.net/pdfs/cdn_issues_CITC_mar10.pdf

Nakache, D. (2010). Temporary workers: Permanent rights? Canadian Issues, 45-54. Retrieved from http://canada.metropolis.net/pdfs/cdn_issues_CITC_mar10.pdf

No Placement Fee May Lead to Rise in Training Costs (2013, July 6-12). Mabuhay. Retrieved from http://mabuhay.catholic.org.hk/print/1079

Ordonez, R. M. (2012). Exporting Filipino graduates to the global labour market: Its implications for Philippine higher education. Asian Education and Development, 1, 43-56. doi: $10.1108 / 20463161211194450$ 
Organization for Economic Development and Cooperation. (2004). Migration for employment: Bilateral agreements at a crossroads. Paris: Author.

Overseas Workers Welfare Association. (2013). Programs and services. Retrieved March 12, 2013 from http://www.owwa.gov.ph:8080/wcmqs/programs_services

Oxman-Martinez, J., Hanley, J., Lach, L., Khanlou, N., Weerasinghe, S., \& Agnew, V. (2005). Intersection of Canadian policy parameters affecting women with precarious immigration status: A baseline for understanding barriers to health. Journal of Immigrant Health, 7, 247-258. doi: 10.1007/s10903-005-5122-2

Paul, A. M. (2011). Stepwise international migration: A multistage migration pattern for the aspirant migrant. American Journal of Sociology, 116, 1842-1886.

Picot, G., \& Sweetman, A. (2012). Making it in Canada: Immigration outcomes and policies. IRPP Study (No. 29). Retrieved from http://www.irpp.org/pubs/IRPPstudy/IRPP_Study_no29.pdf

Piper, N. (2004). Gender and migration policies in Southeast and East Asia: Legal protection and sociocultural empowerment of unskilled migrant women. Singapore Journal of Tropical Geography, 25, 216-231.

Pratt, G. (2006). Separation and reunification among Filipino families in Vancouver. Canadian Issues, 46-49.

Preibisch K., \& Hennebry, J. (2011). Temporary migration, chronic effects: The health of international migrant workers in Canada. Canadian Medical Association Journal, 183, 1033-1038. 
Rodriquez, R. M. (2011). Philippine migrant workers' transnationalism in the Middle East. International Labor and Working-Class History, (79), 48-61. doi:

$10.1017 / \mathrm{S} 0147547910000384$

Ruhs, M. (September 2005). The potential of temporary migration programmes in future international migration policy. Paper prepared for the Policy Analysis and Research Programme of the Global Commission on International Migration.

Ruhs, M. (2012). The human rights of migrant workers: Why do so few countries care? American Behavioral Scientist, 56, 1277-1293. doi: 10.1177/0002764212443815

Seol, D.-h. (2005). Global dimensions in mapping the foreign labor policies of Korea: A comparative and functional analysis. Development and Society, 34, 75-124.

Siemiatycki, M. (2010). Marginalizing migrants: Canada's rising reliance on temporary foreign workers. Canadian Issues, 60-63. Retrieved from http://canada.metropolis.net/pdfs/cdn_issues_CITC_mar10.pdf

Standing Committee on Citizenship and Immigration. (2009). Temporary Foreign Workers and Non-Status Workers. Ottawa: House of Commons.

Statistics Canada. (2013). Immigrant languages in Canada: Language, 2011 Census of Population. Retrieved from http://www12.statcan.gc.ca/census-recensement/2011/assa/98-314-x/98-314-x2011003_2-eng.pdf

Tent city in Jeddah (2013, April 28). Sunday Examiner, pp. 6.

Thomas, D. (2010). Foreign nationals working temporarily in Canada. Canadian Social Trends (Catalogue No. 11-008-X0. Retrieved from http://www.statcan.ca.ca/pub/11-008x/2010002/c-g/11166/c-g010-eng.gif 
Tomic, P., Trumper, R., \& Aguiar, L. L. M. (2010). Housing regulations and living conditions of Mexican migrant workers in the Okanagan valley, B. C. Canadian Issues, 78-82. Retrieved from http://canada.metropolis.net/pdfs/cdn_issues_CITC_mar10.pdf

Tomie, L. (2010). Responsible recruitment of temporary foreign workers in Canada. Canadian Issues, 104-106. Retrieved from http://canada.metropolis.net/pdfs/cdn_issues_CITC_mar10.pdf

Trumper, R., \& Wong, L. L. (2007). Canada's guest workers: Racialized, gendered, and flexible. In S. P. Hier \& S. Singh Bolaria (Eds.), Race and racism in $21^{\text {st }}$-century Canada: Continuity, complexity, and change (pp.151-170). Peterborough, ON: Broadview Press.

Tungohan, E. (2012). Debunking notions of migrant 'victimhood': A critical assessment of temporary labour migration programs and Filipina migrant activism in Canada. In R. S. Coloma, B. McElhinny, E. Tungohan, J. P. C. Catungal, \& L. M. Davidson (Eds.), Filipinos in Canada: Disturbing invisibility (pp.161-180). Toronto: University of Toronto Press.

Watt, D., Krywulak, T., Kitagawa, K. (October 2008). Renewing immigration: Towards a convergence and consolidation of Canada's immigration policies and systems. Ottawa: The Conference Board of Canada. Retrieved from www.conferenceboard.ca

Welsh, S., Carr, J., MacQuarrie, B., \& Huntley. A. (2006). "I'm not thinking of it as sexual harassment": Understanding harassment across race and citizenship. Gender \& Society, 20, 87-107. doi: 10.1177/0891243205282785 